NBER WORKING PAPER SERIES

WHEN LABOR HAS A VOICE IN CORPORATE GOVERNANCE

Olubunmi Faleye

Vikas Mehrotra

Randall Morck

Working Paper 11254

http://www.nber.org/papers/w11254

\author{
NATIONAL BUREAU OF ECONOMIC RESEARCH \\ 1050 Massachusetts Avenue \\ Cambridge, MA 02138 \\ March 2005
}

We are grateful for comments and suggestions from Andrei Shleifer, and from participants in the University of Alberta Finance Seminar; and to John Poole for providing initial seed money for this project, and the Social Sciences and Humanities Research Council and University of Alberta for additional funding. The views expressed herein are those of the author(s) and do not necessarily reflect the views of the National Bureau of Economic Research.

(C2005 by Olubunmi Faleye, Vikas Mehrotra, and Randall Morck. All rights reserved. Short sections of text, not to exceed two paragraphs, may be quoted without explicit permission provided that full credit, including (C) notice, is given to the source. 
When Labor Has a Voice in Corporate Governance

Olubunmi Faleye, Vikas Mehrotra, and Randall Morck

NBER Working Paper No. 11254

March 2005

JEL No. G3, J0

\begin{abstract}
$\underline{\text { ABSTRACT }}$
Equity ownership gives labor both a fractional stake in the firm's residual cash flows and a voice in corporate governance. Relative to other firms, labor-controlled publicly-traded firms deviate more from value maximization, invest less in long-term assets, take fewer risks, grow more slowly, create fewer new jobs, and exhibit lower labor and total factor productivity. We therefore propose that labor uses its corporate governance voice to maximize the combined value of its contractual and residual claims, and that this often pushes corporate policies away from, rather than towards, shareholder value maximization.
\end{abstract}

Olubunmi Faleye

Northeastern University

o.faleye@neu.edu

Vikas Mehrotra

University of Alberta

vmehrotr@ualberta.ca

Randall Morck

Faculty of Business

University of Alberta

Edmonton, CANADA T6G 2R6

and NBER

randall.morck@ualberta.ca 


\section{When Labor Has a Voice in Corporate Governance}

\section{Introduction}

On July 12, 1994, as shareholders approved the recapitalization that rendered United the largest majority employee-owned company in the world, UAL stock closed at $\$ 99.25$. On December 9, 2002, UAL became a penny stock as, unable to sustain the industry's highest labor costs, it filed for bankruptcy protection. Other airlines vehemently opposed aid to UAL, arguing that it had brought on a crisis in the industry by relentlessly driving labor costs up. Robert Roach, Jr., the General Vice President for Transportation at the International Association of Machinists and Aerospace Workers, United's largest union, responded, "Everybody is shocked and concerned that the federal government would not be there for American workers as they are for rebuilding Afghanistan." Sam Buttrick, an airline analyst at PaineWebber summarized that "At the root of the problem is the simple fact that labor has excessive structural leverage". 2

Employee-owned equity blocks are surprisingly commonplace in the United States. According to the National Center for Employee Ownership, as of 2002, employees owned several hundred billion dollars worth of their employers' stock. This includes 11,000 Employee Stock Ownership Plans (ESOPs), stock bonus plans, and profit sharing plans through which 8.8 million workers have over $\$ 400$ billion primarily invested in their employers' stocks - an average investment of about $\$ 45,000$ per employee. In addition, some 11 million employees hold over $\$ 160$ billion of their employers' stocks through some 2,200 401(k) plans - about $\$ 14,000$ per employee. In the past decade, the biggest growth in employee stock ownership has been

\footnotetext{
${ }^{1}$ Quoted in "Unions Vow to Press Fight for Aid Reconsideration", by Matt Richtel and Steven Greenhouse, New York Times, December 5, 2002.
} 
through broad based stock option plans and employee stock purchase plans. Some ten to 25 million employees own several hundred million dollars worth of their employers' stock through some 8,000 of these plans.

These figures translate into a significant tier of employee-owned stock in many large, publicly traded companies. Although employee ownership of public companies through ESOPs and 401(k) plans seldom exceeds ten percent, and that through broad based option and purchase plans seldom exceeds $30 \%$, these stakes are nonetheless substantial enough blocks to matter at shareholder meetings. Since most ESOPs pass voting rights through to employees, and 401(k) plans, broad based stock option plans, and stock purchase plans usually give employees full voting rights, these stakes give employees a substantial voice in the corporate governance of many large publicly traded US firms.

Proponents of employee equity ownership hold that these developments are desirable. Vanek (1965), Drucker (1978), and Aoki (1984) argue that employee equity ownership leads to a convergence of employees' interests with those of shareholders, empowers employees, and lengthens workers' time horizons. They propose that these effects lead to better overall corporate performance. Another argument in favor of employee stock ownership is that labor markets, like capital markets, are imperfect; and that these imperfections might induce managers to make suboptimal decisions. Giving labor a role in corporate governance might mitigate labor market imperfections and improve overall economic welfare. Garvey and Swan (1994), echoing a similar argument, contend that labor ownership may motivate enhanced efficiency given costly and imperfect contracting. Their main premise is that employees, as well as shareholders, are

\footnotetext{
${ }^{2}$ The September 11, 2001 terrorist attacks on New York and Washington devastated the US airline industry. However most airlines analysts recognize that they accelerated an already looming industry financial crisis. See "Righting United Airlines: Nine Flight Plans", by Julie Edelson Halpert, New York Times, September 10, 2000.
} 
residual claimants under incomplete contracting, so vesting some control with labor is ex-ante efficient.

In contrast, Jensen and Meckling (1979) argue that employee equity blockholdings have a dark side - they create an entrenched workforce with corporate governance power. Entrenched labor, like entrenched management, can destroy value as it strives to maximize its utility. Moreover, like entrenched management, entrenched labor cannot be got rid of easily.

Our objective is to test empirically these competing hypotheses regarding the effects of labor ownership and control. We compare several dimensions of corporate decision-making by firms with labor equity ownership and other firms, controlling for exogenous firm characteristics. We find that publicly-traded firms whose employees have a greater voice in corporate governance deviate more from value maximization, spend less on new capital, take fewer risks, grow more slowly, create fewer new jobs, and exhibit lower labor and total factor productivity. These results are highly robust.

We interpret our findings as evidence that extending residual claims to the generality of employees is often not an efficient way to align shareholder and labor interests. Employees, like creditors, primarily hold a fixed claim on the firm's cash flow, in the form of wages and salaries. If labor as a fixed claimant acquires equity ownership, it obtains a residual claim and a voice in corporate governance in addition to its fixed claims. Our evidence is consistent with labor using its corporate governance voice to maximize the total value of its two claims - the fixed, primarily salary-based, claim and the residual equity-based claim.

The corporate strategies that lead to shareholder value maximization and those that maximize the combined value of employees' residual claim and expected future wages and benefits can differ markedly. This is especially so since workers' equity claims are usually small 
compared to the largely fixed claims associated with their wages and benefits. Yet, in a widely held firm, labor's stake may give it a major voice in corporate governance. We propose that this imbalance often allows labor to use its governance voice to push corporate policies away from, rather than towards, shareholder value maximization.

The remainder of the paper is organized as follows. In the next section, we discuss the behavior of labor as a corporate stakeholder and present an overview of the relevant literature. We describe our sample selection procedure in Section III, and report our empirical results in Section IV. Section V contains a brief summary and concluding remarks.

\section{Labor as a Corporate Stakeholder}

Labor's contractual stream of wages is similar to risky debt, in that it consists of a fixed claim on the firm (current and retired labor's stream of promised wages and benefits) less a put option (whose exercise price is the expected value of labor's claim in bankruptcy). That is, as long as the firm's value exceeds the value of labor's claim in bankruptcy, the value of labor's wages is invariant to firm value. For firm value less than labor's claim under bankruptcy, labor's wage claim is reduced a dollar for every dollar reduction in firm value below this threshold. Figure 1 illustrates. Here we generalize the term "bankruptcy" to include any corporate reorganization that reduces or eliminates wages - even if not implemented under formal bankruptcy procedures. Fama and Jensen (1983) argue that governance power should be vested in those who receive a firm's residual claim, and point out that American law reflects this premise. If the put option of bankruptcy is unlikely, employees are usually contractual claimants, receiving a fixed wage, and need no voice in corporate governance. Consequently, American courts hold that corporations be run in their shareholders' interests, with management choosing 
policy variables to maximize shareholder value. Employees' and other creditors' governance rights only come into play in the event of bankruptcy, when their contractual claims expire and they become residual claimants.

A hypothetical alternative legal regime would give complete corporate governance power to current labor. ${ }^{3}$ Labor would choose policy variables to maximize the value of its fixed contractual claims less that of the put option. Given that employees' careers with their firms are finite, we suppose labor has a horizon limitation, beyond which it employs an infinite discount rate. Under these assumptions, labor's objective is equivalent to minimizing the value of the put option. Applying standard results in option pricing theory to a comparison of the two regimes lets us predict how corporate governance in our hypothetical labor-controlled firm might differ from corporate governance in shareholder-controlled firms.

First, all else equal, the option value (which labor seeks to minimize) is lower if cash flows within labor's time horizon are larger. However, what happens to cash flows in periods subsequent to labor's horizon does not affect the option's value. In contrast, the value of a shareholder-controlled firm is larger whenever sacrificing near-term cash flows raises future cash flows sufficiently over any time horizon. Consequently, our hypothetical labor-governed firm would avoid some long-term investments that a shareholder-controlled firm would undertake. Arguably, debt contracts extending beyond current labor's tenure might alleviate this underinvestment. However, this cannot be a complete solution, for external creditors' claims are subordinate to current labor's claim if debt payments are scheduled beyond current labor's employment tenure.

\footnotetext{
${ }^{3}$ German corporate governance law goes far in this direction, for its codetermination rules grant half the seats on corporate supervisory boards to employee representatives.
} 
Second, all else being equal, the option value is lower if the variation in operating cash flow is smaller during current labor's horizon. Thus, labor generally finds projects with volatile cash flows undesirable, regardless of their net present values. This implies that our hypothetical labor-controlled firm should avoid risks that a shareholder-controlled firm would accept.

Third, these differences should slow the growth rates of our hypothetical labor-controlled firms relative to those of shareholder-controlled firms. Possibly, as an unintended benefit, labor ownership might eliminate the over-investment free cash flow problem identified by Jensen (1986). However, labor-managed firms need not follow the NPV rule at all, since labor would rank projects with sufficient cash flows and low risk ahead of potentially higher NPV projects. This suggests that labor-controlled firms might have lower shareholder values, as measured by average Tobin's q ratios, than otherwise similar shareholder-controlled firms.

Finally, it makes sense to envision worker effort as a corporate governance variable in a worker-controlled firm. Shareholder-controlled firms use a variety of incentive systems to encourage workers to work harder. These tools are also at the disposal of our hypothetical worker-managed firm. All else equal, however, labor is only concerned with generating enough cash flow to cover its wages. Any further increase in operating cash flow is unimportant to labor. These considerations suggest that labor-controlled firms might invest less than would shareholder-controlled firms in marginally increased productivity if current cash flows exceed a certain level. In addition, labor may use its governance voice to alter its labor-leisure tradeoff to permit greater leisure. Thus, we would expect lower productivity levels in such firms. 


\section{II.A Labor Control Associated with Equity Ownership by Labor}

In the United States, labor does not gain corporate control rights without acquiring an equity stake. However, if other shareholders' stakes are small, as is often the case in large US firms, equity ownership might give labor a corporate governance voice out of proportion to its equity block holding. Morck et al. (1988) argue that holding a five percent block of stock lets top managers dominate corporate governance. Other authors argue for a higher threshold of control, though there is broad agreement that a stake well below 50\% can confer de facto complete control on the blockholder.

These considerations suggest that labor equity ownership might lead to labor gaining a controlling voice in corporate governance for a small share of the firm's residual cash flows. In such cases, labor's desire to protect its human capital and its fixed wage and benefit contract within a finite horizon has a real effect on corporate policy. Specifically, labor control, obtained with only a small labor ownership stake, might lead to reduced long-term investment, risk avoidance, slower growth, less concern with share value maximization, and/or reduced productivity.

\section{II.B Previous Work}

Previous work searches for productivity and incentive effects of labor equity ownership. One approach consists of examining abnormal returns around labor's acquisition of equity blocks through ESOPs. An ESOP is a tax-qualified defined contribution retirement plan established under the Employee Retirement Income Security Act (ERISA) of 1974 that invests most of its assets in the employer's stock. Thus, the creation of an ESOP can result in employees acquiring a significant block of shares. Consequently, an examination of ESOP announcement returns could 
provide an insight into the effect of labor ownership. However, results of ESOP announcement studies have been inconclusive. For instance, while Chang (1990) finds positive abnormal returns, Gordon and Pound (1990) report an insignificant average announcement period return.

ESOPs enjoyed special tax privileges and are subject to provisions not applicable to other ownership plans. This can create problems in interpreting empirical findings and may be partially responsible for the inconclusive results. For example, does a positive abnormal return upon an ESOP announcement reflect expectations of changed labor productivity or expectations of tax breaks? Scholes and Wolfson (1990), Chaplinsky and Niehaus (1990), and others argue that the tax effects of ESOPs are limited and not necessarily bigger than those provided by other employee compensation plans. However, Beatty (1995) reports that ESOP announcement abnormal return is significantly positively related to estimated tax benefits.

Further interpretation problems arise because ESOPs often arise in connection with corporate takeover defenses. Gordon and Pound (1990) argue that the management of a potential takeover target can create an ESOP to modify the firm's ownership structure in its favor by placing a block of shares in friendly hands. Thus, ESOPs could be used as a managerial entrenchment tool. However, as Stulz (1988) argues with respect to anti-takeover activities in general, management might also use the ESOP as leverage to gain better terms for shareholders in a takeover contest. For these reasons, it is difficult to understand the complete effects of employee ownership by analyzing ESOP announcement abnormal returns.

Another approach is to estimate the effect of employee ownership on labor productivity and accounting measures of corporate performance. Again, results have not been conclusive. Bloom (1986) utilizes a series of augmented Cobb-Douglas production functions to evaluate the effects of employee ownership on productivity at the firm level. He estimates the functions 
cross-sectionally and longitudinally for a large sample of manufacturing and non-manufacturing firms. He concludes that employee ownership has little or no impact on corporate performance. In contrast, Beatty (1995) performs a similar analysis and reports that ESOPs increase sales per employee in the first two post ESOP-adoption years if the ESOP replaces no other retirement benefit plan. Park and Song (1995) report significant improvements in performance (as measured by return on assets, Tobin's q, and market-to-book ratio) in the three years following plan establishment. However, such improvements are contingent on the presence of an external blockholder. Lougee (1999) investigates the long-term effects of ESOP adoption. She concludes that her tests provide no evidence that ESOPs improve firm performance.

A potential problem with studies that focus on the immediate post-ESOP years is that they may capture the residual effects of financial circumstances associated with takeover threats or defenses. This matters since ESOPs are sometimes created as takeover defenses or liquidity enhancements programs in the presence of financial difficulties. In addition, given the stock allocation rules followed by most ownership plans, it apparently takes time for corporate policies and results to reflect the effects of employee influence on management.

We address these difficulties in two ways. First, we consider all labor-owned equity blocks, not just those associated with ESOPs. Since much labor ownership in US publicly traded firms does not arise out of ESOPs, this provides us with a substantially larger sample and affords us the opportunity to examine possible differences arising from the mode of labor ownership. Second, to avoid temporary or unusual financial circumstances associated with the events leading up to an ESOP, we require that blocks of labor ownership be in place for several years before we admit a firm to our sample of labor-controlled firms. By not including the immediately 
ensuing years, we examine firms more likely to be subject to labor's governance influences. We thus focus on long-term steady state implications of labor equity ownership.

Another concern with focusing on labor ownership is that control does not automatically follow ownership. Chang and Mayers (1992) discuss how de jure labor equity blocks can become de facto management ownership. Indeed, corporate management, not labor or its representatives, explicitly votes many labor equity blocks. Including such blocks is appropriate in other contexts, but not in this study. This is because control over voting shares translates into corporate governance influence, and hence into the strength with which labor's objectives become manifested in corporate policy.

Labor-voted equity stakes clearly give labor a voice in corporate governance decisions. McElrath and Rowan (1992) find that unions view employee ownership as a way of influencing strategic decision making and restricting management's largely "unchecked independence". Anecdotal evidence concurs. For example, Northwestern Steel \& Wire Co. places at least one ESOP representative on its board if its ESOP owns a minimum 5\% of the outstanding shares. Similarly, labor nominates four of Weirton Steel's fourteen directors; and three of UAL's twelve directors represent employees. McKersie (1999) reports that most corporate boards make major decisions by consensus, and that this often gives labor-nominated directors significant leverage. He quotes one labor-nominated director: "If you work within the system, you can either get a lot accomplished or get some projects struck down, even though your opinion may at first be in the minority." McKersie quotes another labor-nominated director's experience with consensus: "On what I thought was a fairly minor issue, but one that I felt strongly about, I cast the only opposing vote on the board. It caused a great deal of problems; the other directors could not understand how I could be opposed after hearing their point of view. Because there is a tendency 
to move only on unanimity, it gives (labor-nominated) directors much more influence than I ever expected we had."

In other cases, employees influence corporate policies directly, i.e., without necessarily having board representation. For example, the labor union at Marriott International, working with other investors, won a 1998 proxy contest to prevent Marriott's proposed dual-class recapitalization. The company had intended the dual-class structure as an integral part of its plan to split its food service and hotel businesses. Similarly, UAL aborted its acquisition of USAir in 1995 because of employee opposition. Voting power clearly enhances employees' ability to influence corporate decisions. We are therefore interested in firms where labor votes its stock, but not in firms where managers vote labor's shares.

\section{Empirical Framework}

\section{III.A Sample Construction}

We begin with the 3,823 definitive proxy statements filed with the Securities and Exchange Commission in 1995. We then exclude filings by mutual funds, real estate investment trusts, limited partnerships, subsidiaries, and firms with incomplete data in COMPUSTAT. This yields an initial universe of 2,165 proxy statements. We read each of these filings to determine the proportion of voting shares owned by employees of each firm.

We identify 277 firms where employees own at least five percent of outstanding shares as reported in the beneficial ownership section of the proxy statement. In 22 of these firms, management exercises the right to vote employee-owned shares. For example, corporate executive officers, serving as ESOP trustees, vote a twenty percent ESOP block in Security National Financial. Similarly, five company officers exercise voting control over the $17.95 \%$ 
block of Central Steel \& Wire's profit sharing plan. Since we are interested in labor's corporate control voice, not simply de jure labor ownership, we drop these 22 firms, reducing the sample to 2,143 . Of these, employees control at least five percent of voting shares in 255 firms. We classify these as subject to some degree of labor voice in corporate governance. ${ }^{4}$

We then checked earlier proxy statements for each of the 255 labor voice firms to determine the year labor ownership passed the 5\% threshold. We denote this as the event year for the firm. We exclude 29 firms with event years later than 1990. This is because we wish to examine the steady state effects of employee voice in corporate control, and employee stock ownership can sometimes result from corporate restructuring under financial distress. By requiring at least five years of labor influence prior to the empirical window we examine, we hope to mitigate the effects of any temporary financial problems that might have been associated with labor accumulating stock. ${ }^{5}$

Thus, our final labor voice sample consists of 226 firms. Of these, 110 are firms in which labor acquired its stake through an ESOP. In 75 firms, labor acquired its stake through nonESOP means: profit sharing, stock bonuses, stock savings, stock purchases, or combinations of these and other retirement benefit plans. Labor acquired its equity stake through a combination of ESOPs and other channels in the remaining 41 firms. Table 1 summarizes the distribution of labor ownership among the labor voice firms. Mean and median labor ownership are $13.16 \%$ and $10.60 \%$, respectively. The minimum stake controlled by labor is five percent, while the maximum is $68.20 \%$. By way of comparison, mean and median non-affiliated block equity

\footnotetext{
${ }^{4}$ For e.g., Morck, Shleifer and Vishny (1988) find that entrenchment effects begin to dominate at 5\% management ownership. Also note that the SEC uses a five percent threshold for Schedule 13D filings under the Williams Act incorporated in the Securities Exchange Act of 1934.

${ }^{5}$ Admittedly, this approach may introduce some survivorship bias into our analysis, since labor voice firms must survive at least five years after the event year to be part of our sample. However, this should bias results in favor of the labor voice firms.
} 
holdings among the labor voice firms are $8.79 \%$ and $6.00 \%$, respectively, while mean and median managerial ownership for these firms are $13.60 \%$ and $6.83 \%$, respectively. Thus, labor is the largest blockholder in the typical labor voice firm.

Our control sample consists of the 1,888 firms reporting no labor equity ownership or ownerships lower than five percent in their proxy statements. We regard these firms as largely free from labor influences in corporate governance.

\section{III.B Variable Definitions}

Our basic strategy is to run regressions explaining corporate performance and strategy variables with measures of labor voice and a set of control variables. This section first describes our labor voice measures, and then describes the variables employed in our financial performance regressions. Finally, we describe variables in the other regressions we also run.

\section{Labor Voice Measures}

We measure labor voice in several ways. One set of approach uses indicator variables set to one if labor votes more than a certain fraction of the shares at the company's annual general meeting. We use five, ten, fifteen, and twenty percent thresholds. A second approach uses the fraction of labor-voted shares as a continuous variable. We also experiment with more complicated specifications, including quadratic and piecewise linear terms. These add no significant explanatory power. The relationship between labor voice and our various dependent variables is always monotonic.

\section{Financial Performance Regressions}

Our primary goal is to understand how a labor voice affects corporate governance. A major aspect of corporate governance is the creation of wealth for shareholders, which we measure by Tobin's average q approximated as the market value of common equity plus book 
values of preferred equity and long-term debt divided by the book value of assets less short-term debt. Although it is possible to construct more sophisticated versions of Tobin's q, Chung and Pruitt (1994) show that this relatively simple version performs quite as well as more complicated ones. Besides, more sophisticated measures require additional data, which reduces sample size and creates another set of econometric problems. Recent studies that employ the simple measure of Tobin's q include Callahan et al (2003) and Hartzell and Starks (2003).

We do not include regressions explaining profitability measures such as return on asset (ROA) or profit margins (ROS) as alternate specifications. This is because these variables measure short-term performance. Although short-term performance might be depressed by some governance problems, it might also be elevated by other effects. For example, profits might be elevated if risk averse labor voice firms sacrificed long-term performance to build up a cash cushion. In a sufficiently efficient stock market, market-to-book ratios incorporate such tradeoffs and accurately reflect net gains in present value terms. Of course, market irrationality, among other things, can distort market-to-book ratios. When we rerun the regressions in our tables with ROA or ROS as the dependent variable, our labor voice measures are insignificant.

We recognize that labor voice is only one of many variables that may affect a firm's ability to create wealth. To estimate the marginal effect of labor influence, we must control for other governance and non-governance factors related to Tobin's q. These include board size (Yermack, 1996), board composition (Rosenstein and Wyatt, 1990), leadership structure (Rechner and Dalton, 1991), managerial equity ownership (Morck et al, 1988), ${ }^{6}$ block ownership (Bethel et al., 1998), the availability of investment opportunities (Yermack, 1996), and current

\footnotetext{
${ }^{6}$ Following Morck et al. (1988), the empirical corporate finance literature typically uses breakpoints to control for managerial ownership. We employ the same breakpoints as in Morck et al. (1988), i.e., ownership levels of less than $5 \%$, between $5 \%$ and $25 \%$, and greater than $25 \%$. Our results are invariant to other breakpoints, as well as to a single continuous measure of managerial ownership.
} 
profitability (Yermack, 1996). We hand-collect governance data (board size, board composition, leadership structure, managerial equity ownership, and block ownership) from 1995 proxy statements and use the ratio of capital expenditures to total assets as a proxy for the availability of investment opportunities. Our measure of current profitability is return on assets, defined as the ratio of operating income to total assets at the beginning of the year. We obtain data on capital expenditures, operating income, and total assets from COMPUSTAT.

In addition, we control for debt because leverage may alter a firm's contracting environment and significantly enhance or hinder its ability to create shareholder wealth. We measure leverage as the ratio of long-term debt to total assets using data from COMPUSTAT. We also control for whether managers' compensation is tilted toward equity or debt-like, fixed payoffs because equity compensation may affect managerial incentives. Our measure of the structure of managerial compensation is the ratio of the CEO's option compensation to total compensation, which we compute using data from Execucomp. Finally, we employ two-digit SIC code dummies to control for industry effects, and use the logarithm of total assets (in 1994 dollars) to control for firm size.

As indicated earlier, we wish to focus on long-run steady state effects. We thus compare our labor voice firms to control firms over the seven-year period 1995 to 2001 . However, it is possible that labor ownership resulted from past financial problems. For example, labor ownership can result from a bailout of the company using pension fund money to set up an ESOP, as at Morrison Knudsen Corp in September 1988. Labor ownership may also arise as a concession to unions in return for taking pay cuts, as at United Airlines. Establishing a laborowned equity block can also serve as a defensive move against an actual or feared hostile takeover, as in the well-known Polaroid case. Since Morck et al (1989) and others show that 
hostile takeovers in this period were often preceded by poor financial performance, a spurious correlation problem is again possible, i.e., past performance can result in labor control, as well as affect the dependent variable. In Section III.A, we required labor voted equity blocks to have been in place for at least five years before admitting firms to our labor voice sample to circumvent this problem. Nevertheless, we consider a number of variables to control for possible remaining aftereffects of past financial circumstances.

The first of these is average ROA calculated for each firm over 1985 to 1989. Including this variable should thus capture echoes of any financial problems that triggered the formation of the labor equity block. As a robustness check, we also use average historical Tobin's q ratio, calculated also over 1985 to 1989 . Our results are not sensitive to the measure of past financial performance. As a further robustness check, we rerun all our regressions including first ROA estimated from 1990 through 1994 and then Tobin's q averaged over the same period. The results again remain virtually unchanged.

\section{Other Regressions}

In addition to the shareholder value tests, we also compare several other dimensions of corporate decision making for the labor voice and control firms. These dimensions are long-term investment, operating risk, growth, and labor and total factor productivity. We discuss our measures for these variables below.

We consider two sorts of long-term investment as alternate dependent variables. The first, an investment rate, is denoted $d K / K$, and is capital expenditure on new property, plant and equipment, normalized by total net property, plant, and equipment. The second is research and development spending, also normalized by net property, plant, and equipment and denoted 
$R \& D / K$. Where all other main financial variables (sales, assets, and net income) are reported, but R\&D is not, we presume it to be negligible and set it to zero.

Our measure of operating risk is the standard deviation of return on assets. For each year $t$, we calculate the standard deviation of return on assets over the current year and the three preceding years, i.e., years $t, t-1, t-2$, and $t-3$. We define return on assets as the ratio of operating income before depreciation, interest, and taxes to total assets at the beginning of the year.

We define two measures of corporate growth, namely, sales growth and labor force growth. Sales growth is the three-year average growth rate of real sales calculated as

$$
\Delta \text { Sales }_{t}=\frac{\alpha_{t} \text { Sales }_{t}-\alpha_{t-3} \text { Sales }_{t-3}}{3 * \alpha_{t-3} \text { Sales }_{t-3}}
$$

for each year $t$, where $\alpha$ is the GDP deflator. Labor force growth rate is constructed analogously, but without the GDP deflator.

To estimate total factor productivity $(T F P)$, we assume that each firm's sales are generated by a Cobb-Douglas production function of the form

$$
Y_{i t}=A L_{i t}^{\beta} K_{i t}^{\alpha}
$$

where $Y_{i t}$ is net sales for firm $i$ in period $t, L_{i t}$ is the number of employees, $K_{i t}$ is net property, plant, and equipment, and $A, \alpha$, and $\beta$ are parameters. Unlike Bloom (1986) and Beatty (1995), we do not assume a labor ownership augmentation parameter. Rather, we employ residuals from our estimation of the logarithmic transformation of [2] as a measure of firm-level TFP, and look for any effect associated with labor voice in these residuals. We control for industry factors by estimating a separate equation for each two-digit SIC industry group.

We compare labor productivity as well as total factor productivity. We measure labor productivity by the simple ratio of real sales to the number of employees. 


\section{III.C Statistical Tests and Robustness Checks}

We begin our analysis by contrasting the means and medians of the dependent variables defined in the previous section for labor voice and control firms. We recognize that these variables are often not entirely within management's control, and so univariate results may sometimes be misleading as indicators of managers' intentions, or corporate policies. We therefore follow simple comparisons of these variables across the two samples with multiple regression analysis. This allows us to control for exogenous factors that may affect each aspect of corporate decisionmaking.

\section{Empirical Results}

\section{IV.A Shareholder Value}

Panel A of Table 2 shows that average and median Tobin's q for labor voice firms during $1995-2001$ are 1.019 and 0.875 , respectively. These are significantly lower, at the $1 \%$ level or better, than the corresponding figures for other firms, 1.433 and 1.026. Similarly, although not reported in Table 2, average and median Tobin's q are significantly lower for labor voice firms in each of the seven years, with p-values of 0.05 or less. These results provide preliminary evidence of significantly less effective shareholder wealth maximization in firms whose corporate governance is influenced by a labor voice.

Table 3 presents regressions of Tobin's q on labor voice and the governance and other controls described in Section III.B. The first column controls for prior financial circumstances using historical Tobin's q, and uses a continuous measure of labor voice, the percentage of shares voted by employees. Its coefficient is -0.0158 , which is significant at the $1 \%$ level. This 
implies that the difference between no labor voice to a $10 \%$ labor voted block, the median in the labor voice subsample, is a Tobin's q depressed by $16 \%$ in the latter. A similar result obtains if we measure labor control using an indicator variable equal to one if labor votes at least five percent (column II). The coefficient of -0.2296 implies that labor voice is associated with a $23 \%$ reduction in Tobin's q. Columns III and IV control for prior financial circumstances using historical return on assets. Labor voice variable remains negative and significant at the $1 \%$ level.

We also estimate cross-sectional regressions similar to those in Table 3 for each of the seven years in our data. Labor voice is negative and statistically significant at the $5 \%$ level or less in each year. Furthermore, we estimate regressions (not reported) for which the dependent variable is the change in average Tobin's q from 1985-1989 to 1995-2001. We obtain similar results: Labor voice is significantly negatively related to the change in average Tobin's q, with pvalues lower than 0.05 .

A reasonable concern with the above results is whether a five percent equity ownership translates into a meaningful governance voice for labor. If not, the regression results may simply be picking up other unknown factors associated with labor ownership that depress shareholder value. We address this concern by digging deeper into the ownership structure of each of our sample firms to identify those cases where labor ownership is most likely to translate into a significant corporate governance voice.

A natural starting point is to raise the minimum employee ownership level required for a firm to be considered as subject to labor influence in corporate governance. We therefore repeat our regressions using the subset of firms with minimum labor-controlled equity stakes of $10 \%$, $15 \%$, and $20 \%$, respectively, in place of the full sample of labor voice firms. Results of these regressions appear in Table 4. As the table shows, the labor voice dummy is negative and 
significant at less than the 5\% level in each case. In addition, the coefficient becomes more negative as we increase the minimum stake, from -0.388 for $10 \%$ stakes to -0.530 for $20 \%$ stakes. Note also that there are only 23 firms with labor-voted equity stakes of at least $20 \%$ (column III). The significant negative coefficient for labor control in this regression suggests a particularly strong underperformance by the labor voice firms.

Labor's ability to influence corporate governance may depend not only on the absolute voting stake controlled by employees, but also on the makeup of the firm's other shareholders. For example, a labor stake of even $20 \%$ may mean nothing if managers own $50 \%$ of the outstanding shares. Similarly, a strong influence may not necessarily accompany labor's equity ownership if there are other significant outside blockholders. For these reasons, Table 5 repeats our analysis using only the subsets of labor voice firms where labor owns $10 \%, 15 \%$, and $20 \%$ of the shares and this stake is the single largest block in the company's ownership structure. We believe labor's ability to influence corporate policies is probably greatest in these cases. Again, the labor voice variable is negative and statistically significant in each regression. Overall, our results are inconsistent with labor voting power entailing a convergence of interest between outside shareholders and employees. Rather, there is strong indication of a considerable reduction in corporate value creation as measured by Tobin's q ratio.

\section{IV.B Long-term Investment}

Panel A of Table 2 presents univariate statistics for capital investment rates and research and development spending for our labor voice and control firms. As the table reveals, both measures of long-term investment are significantly lower in labor voice firms. The average capital investment rate of labor voice firms is $8.4 \%$ compared to $13.3 \%$ for other firms. 
Similarly, R\&D expenditure for labor voice firms average $1.3 \%$ of total assets, compared to $3.1 \%$ for control firms. In each instance, the difference is significant at the $1 \%$ level. Similar results hold with respect to medians. ${ }^{7}$

These univariate results suggest that labor's voice might deter long-term investment. Again, prior poor performance in labor voice firms might affect these results. We therefore control for historical financial performance. We also include controls for firm size and several dimensions of corporate governance as well as the firm's investment opportunity set. In addition, each regression includes two-digit SIC code dummies to control for unobservable industry factors.

Column I of Table 6 presents summary results from regressions for capital investment rate. The first row measures labor influence using the percentage of votes controlled by labor, while rows two through four use five percent, ten percent, and fifteen percent threshold dummies, respectively, to distinguish labor voice firms. Consistent with the univariate results, Table 6 reveals a negative significant relationship between labor voice and capital spending. The estimated coefficients imply that, after controlling for past financial circumstances and other factors, a ten percentage point increase in labor-controlled equity reduces capital spending by about two percent, while a labor voice in corporate governance (as measured by the five percent ownership dummy) is associated with a $2.59 \%$ reduction in long-term investment. Since the mean and median of capital spending are about twelve and seven percent, respectively, of net property, plant and equipment, these are economically significant effects. ${ }^{8}$

\footnotetext{
${ }^{7}$ We also compute industry-adjusted R\&D expenditures based on 2-digit SICs, and find similar results, i.e., labor voice firms invest significantly less in R\&D than do control firms.

${ }^{8}$ Only 25 firms with labor stakes higher than $20 \%$ have sufficient data for similar regressions. For this group, the labor voice dummy is not significant, although it is negative.
} 
The second and third columns of Table 6 present results of regressions for research and development expenditure. Since we do not have real economic depreciation data for R\&D investments, our dependent variable is left censored. We thus employ Tobit, rather than OLS, regressions. As column II shows, the labor voice variable is not significant in each regression estimated over the full sample. However, when we restrict the sample to firms that actually invest in R\&D during the period, the labor voice variable (as measured by the percentage of labor-controlled equity, as well as the five- and ten-percent ownership dummies) is negative and statistically significant at the $5 \%$ level, as reported in the third column of Table 6 . Recall that more than half of our sample firms report no $R \& D$ expenditure during the entire seven-year empirical window of our study. These results suggest that labor voice firms that invest in R\&D invest less than otherwise similar control firms.

As robustness checks, we rerun all of the above procedures using alternative long-term investment measures normalized by total assets and total sales. Using these variants does not change our qualitatively conclusions. Further, if we partition the sample into ESOP firms and firms with other types of labor ownership, we find no significant differences in the effect of labor voice, i.e., labor voice firms tend to reduce long-term investment, irrespective of the means through which labor acquired ownership.

These results are hard to reconcile with the hypothesis that labor equity ownership causes workers to advocate shareholders' interests. McConell and Muscarella (1985) show that stock prices rise when firms announce increases to their capital budgets. Chan et al. (1990) show that similar positive abnormal returns accompany announcements that firms are increasing their $R \& D$ budgets. Likewise, Eberhart et al. (2004) report significantly positive long-term abnormal operating performance following $\mathrm{R} \& \mathrm{D}$ increases. These studies and others suggest shareholders 
believe most firms underinvest in long-term projects. The depressed shareholder value associated with labor voice in section IV.A undermines any argument that labor voice firms might be curtailing value-destroying excess capital spending and $R \& D$.

\section{IV.C Operating Risk}

Panel A of Table 2 presents univariate comparisons of operating risk for labor voice and other firms. Mean and median operating risk for labor voice firms are 3.5\% and 2.9\%, respectively. These are significantly lower at $1 \%$ level or better than the comparable figures for other firms, $5.5 \%$ and $3.9 \%$, respectively. Results are similar when we measure operating risk using the standard deviation of operating income scaled by sales.

Column IV of Table 6 presents summary results from regressions for operating risk analogous to those in the preceding columns for long-term investment and R\&D expenditure. In the first row, labor voice is labor's percentage voting power. Its coefficient is negative and significant at the $1 \%$ level. In the second through the fourth rows, labor voice is a dummy variable for $5 \%, 10 \%$, and $15 \%$ labor equity ownership, respectively. In each case, the coefficient is negative and significant at the $10 \%$ level or better.

As a robustness check, we substitute the standard deviation of return on sales, estimated over the same period, as the measure of operating risk. Qualitatively similar results ensue. Next, we partition the sample into ESOP firms and firms with other types of labor ownership. We find some differences in the effect of labor voice based on the sample partition. The labor voice variable is negative and significant for ESOP firms. On the other hand, it is never significant in the regressions for firms with other types of labor ownership, although it is also always negative. 
Thus, it appears that the operating risk results are driven by ESOP firms, which represent $49 \%$ of our sample of labor voice firms.

Table 6 indicates that a labor voice in corporate governance is associated with a significant reduction in corporate risk taking. This is consistent with risk-averse employees biasing their firms' investment and other decisions to reduce risk. It also provides further evidence that labor influence in corporate governance need not promote a convergence of interest between employees and public shareholders. Overall, the evidence on operating risk is consistent with labor voice firms curtailing risky investments.

\section{IV.D Corporate Growth}

Panel A in Table 2 displays univariate statistics for real sales and labor force growth rates. Over the seven-year comparison period, labor voice firms achieved average and median sales growth rates of $8.6 \%$ and $5.7 \%$, respectively; significantly below comparable figures for other firms of $13.8 \%$ and $8.7 \%$ at $1 \%$ level or better. Perhaps more importantly, labor voice firms create only about half as many net new jobs as other firms. Note that to maintain or increase individual labor's wages while simultaneously increasing total labor force would require profitability and/or efficiency improvements. We have argued and presented evidence against both elsewhere in the paper. Put differently, our evidence suggests that labor dislikes a dilution of its claims to corporate revenues (including quasi-rents in the form of excess wages or benefits), just as equity holders dislike a dilution of their claims with new issues.

Columns V and VI of Table 6 regress real sales and labor force growth rates on labor voice and our standard controls, including historical profitability to control for past financial circumstances and 2-digit SIC code dummies for industry factors. The first row uses a continuous 
labor voice stake, while the second through the fourth rows use labor control thresholds of 5\%, $10 \%$, and $15 \%$, respectively.

The coefficients of the labor voice dummy in columns V and VI of Table 6 are negative and significant for all regressions. The parameter estimates suggest that, after controlling for other aspects of a firm's corporate governance and financial circumstances, real sales growth is lower for labor voice firms by $3 \%$ to $5 \%$, while employment growth is lower by $3 \%$ to $4.5 \%$. When labor voice is measured with a continuous variable, the coefficients are $-0.22 \%$ for sales growth and $-0.19 \%$ for staff growth, indicating that a ten-percentage point increase in laborcontrolled votes reduces real sales growth by $2.2 \%$ and employment growth by $1.9 \%$. These results do not depend on the mode of labor ownership. Separating ESOP firms from other firms with labor voice yields virtually identical results in each subsample.

\section{IV.E Productivity}

Univariate results for total factor productivity residuals are shown in Panel A of Table 2. The average total factor productivity residual for labor voice firms is -0.011 , significantly below the 0.070 average for other firms at the $1 \%$ level. Similarly, median productivity residual for labor voice firms is -0.032 , compared to 0.050 for other firms. Again, the difference is significant at the $1 \%$ level. Thus, while the actual output of a typical non-labor-controlled firm represents $105 \%$ of what we would expect based on factor inputs, labor voice firms manage to produce only about $97 \%$ of expected output on average. This clearly suggests that labor influence in corporate governance is associated with noticeably depressed firm-level productivity.

Column VII of Table 6 examines the robustness of this association to controls for other aspects of firm governance and financial circumstances by regressing total factor productivity 
residuals on measures of labor voice and the control variables from Section III.B. The first regression measures labor influence using the proportion of shares voted by employees, while the second, third, and fourth regressions use indicators variables corresponding to 5\%,10\%, and $15 \%$ labor ownership, respectively.

As Table 6 reveals, labor voice is negative and significant in each regression. These results confirm the univariate findings of a substantial depression in factor productivity at laborcontrolled firms. In particular, the coefficient of the labor voice dummy becomes more negative at higher employee voting thresholds without losing its statistical significance, despite sharply reduced numbers of firms satisfying the labor voice definition.

A similar conclusion follows for labor productivity. Although Table 2 shows mean and median sales per employee to be statistically indistinguishable, column VIII of Table 6 reveals significantly depressed labor productivity in labor voice firms. Again, the effect is more negative at higher thresholds of employee ownership. The coefficient estimates imply that, compared to other firms, real sales per employee is lower by about $17.84 \%$ in firms where employees control $15 \%$ or more of outstanding voting shares, while labor-voting power ten-percent higher is associated with a real sales per employee $5.4 \%$ lower. These productivity results suggest that the depressed employee and total factor productivities in labor voice firms are economically, as well as statistically, significant.

We note that our results are not inconsistent with Beatty (1995), who finds depressed and enhanced productivity associated with ESOPs depending on whether they replace existing pension plans or not. First, ESOPs usually replace existing pension plans. Second, Beatty (1995) studies sales per employee during the first two post-ESOP adoption years. Since troubled firms often establish ESOPs as they restructure, a productivity rebound effect is possible - especially 
in firms that are not in such serious difficulty that they must sacrifice their existing pension plans. We exclude the first five years of employee ownership precisely to allow effects of such contingent events to fade, and to allow time for employees to use their governance voice to affect corporate decision-making.

\section{Conclusions}

Our empirical findings reveal that a longstanding labor voice in corporate governance is associated with significantly depressed shareholder value, sales growth, and job creation. This, in part at least, appears to reflect a systematic avoidance of certain types of investment - capital expenditure, R\&D spending, and high-risk investments in general. It also probably reflects depressed labor and total factor productivity in firms whose employees influence corporate governance.

We argue that current labor rationally uses its voice to maximize the value of its equity stake plus the present value of its expected future wages and benefits. Since the present value of future wages and benefits is much larger relative to the present value of labor's equity stake in most cases, Jensen and Meckling (1979) argue that labor is primarily concerned with maintaining current and future cash flows sufficient to prevent wage or benefits cuts. This, combined with current labor not greatly valuing cash flows that accrue in the distant future, beyond their wage and benefits horizons, explains a low-risk, low-investment, and low-growth strategy. Depressed productivity may simply reflect labor using its voice to enhance its labor-leisure tradeoff to attain greater leisure. However, it might also reflect depressed investment in innovation, which might erode the value of current labor's firm-specific human capital. Further work is needed to clarify these issues. 
Our findings cast a serious doubt on the simple premise that labor equity participation causes a convergence of interests between workers and shareholders. It appears that the increased governance role acquired by labor following an ownership stake allows employees to influence corporate policies in ways beneficial to their narrow interests. Labor appears to use its voice in corporate governance to inject employee horizon and firm-specific human capital concerns into the firm's objective function as it maximizes the combined value of its contractual and residual claims. This often pushes corporate policies away from, rather than towards, shareholder value maximization. 


\section{References}

Aoki, Masahiko. 1984. The Cooperative Game Theory of the Firm. Oxford University Press.

Beatty, Anne, 1995, The Cash Flow and Informational Effects of Employee Stock Ownership Plans, Journal of Financial Economics 38, 211-240.

Bethel, Jennifer, E., Julia P. Liebeskind, and Tim Opler, 1998, Block share purchases and corporate performance, Journal of Finance 53, 605-634.

Bloom, Steven, 1986, Employee Ownership and Firm Performance, Ph.D. Dissertation, Harvard University, Boston, MA.

Callahan, William T., James A. Millar, and Craig Schulman, 2003, An analysis of the effect of management participation in director selection on the long-term performance of the firm, Journal of Corporate Finance 9, 169-181.

Chan, Su Han, John D. Martin, and John W. Kensinger, 1990, Corporate Research and Development Expenditures and Share Value, Journal of Financial Economics 26, 255276

Chang, Saeyoung, 1990, Employee Stock Ownership Plans and Shareholder Wealth: An Empirical Investigation, Financial Management 19, 48-58.

Chang, Saeyoung and David Mayers, 1992, Managerial Vote Ownership and Shareholder Wealth: Evidence from Employee Stock Ownership Plans, Journal of Financial Economics 32, 103-131.

Chaplinsky, Susan and Greg Niehaus, 1990, The Tax and Distributional Effects of Leveraged ESOPs, Financial Management 19, 29-38.

Chung, Kee H., and Stephen W. Pruitt, 1994, A simple approximation of Tobin's q, Financial Management 23, 70-74.

Eberhart, Allan C., William F. Maxwell, and Akhtar R. Siddique, 2004, An Examination of Long-Term Abnormal Stock Returns and Operating Performance Following R\&D Increases, Journal of Finance 59, 623-650.

Fama, Eugene, and Michael C. Jensen, 1983, Separation of ownership and control, Journal of Law \& Economics 26, 327-349.

Garvey, Gerald T. and Peter L. Swan, 1994, The economics of corporate governance: Beyond the Marshallian firm, Journal of Corporate Finance 1, 139-174.

Gordon, Lilli and John Pound, 1990, ESOPs and Corporate Control, Journal of Financial Economics 27, 525-555.

Hartzell, Jay C. and Laura T. Starks, 2003, Institutional Investors and Executive Compensation, Journal of Finance 58, 2351-2374.

Jensen, Michael, 1986. Agency Costs of Free Cash Flows, Corporate Finance and Takeovers. American Economic Review 76, 323-329. 
Jensen, Michael C. and William H. Meckling, 1979, Rights and Production Functions: An Application to Labor-Managed Firms and Codetermination, Journal of Business 52, 469506.

Lougee, Barbara., 1999, An Empirical Investigation of the Implications of Employee Ownership for the Agency Problem and the Information Content of Earnings. Ph.D. Dissertation, Cornell University, Ithaca, NY.

McConnell, John J. and Chris J. Muscarella, 1985, Corporate Capital Expenditure Decisions and the Market Value of the Firm, Journal of Financial Economics 14, 399-422.

McElrath, Roger G. and Richard L. Rowan, 1992, The American Labor Movement and Employee Ownership: Objections to and Uses of Employee Stock Ownership Plans. Journal of Labor Research 13, 99-120.

McKersie, Robert B., 1999, Union-Nominated Directors: A New Voice in Corporate Governance, Working Paper, Massachusetts Institute of Technology, Cambridge, MA.

Morck, Randall, Andrei Shleifer, and Robert Vishny, 1988, Managerial Ownership and Market Valuation: An Empirical Analysis, Journal of Financial Economics 20, 293-315.

Morck, Randall, Andrei Shleifer, and Robert Vishny, 1989, Alternative Mechanisms for Corporate Control, American Economic Review 89, 842-852.

Park, Sangsoo and Moon H. Song, 1995, Employee Stock Ownership Plans, Firm Performance, and Monitoring by Outside Blockholders, Financial Management 24, 52-65.

Rechner, Paula L. and Dan R. Dalton, 1991, CEO duality and organizational performance: A longitudinal analysis, Strategic Management Journal 12, 155-160.

Rosenstein, Stuart, and Jeffrey Wyatt, 1990, Outside directors, board independence, and shareholder wealth, Journal of Financial Economics 26, 175-192.

Scholes, Myron and Mark Wolfson, 1990, Employee Stock Ownership Plans and Corporate Restructuring: Myths and Reality, Financial Management 19, 12-28.

Stulz, René, 1988, Managerial control of voting rights, financing policies, and the market for corporate control, Journal of Financial Economics 20, 25-54.

Yermack, David, 1996, Higher market valuation of companies with a small board of directors, Journal of Financial Economics 40, 185-213. 


\section{Figure 1: Shareholders' and labor's claim on the firm's cash flow.}

In periods when the firm's cash flow is lower than $\omega$ (that is, the region to the left of $\omega$ in the graph), labor receives all cash flow in the form of wages. If cash flow is greater than $\omega$ (the region to the righ of $\omega$ ), then labor receives its fixed payment $(\omega)$ while shareholders receive the excess of cash flow over $\omega$ in the form of dividends. The figure assumes that shareholders are the sole residual claimants in the firm.

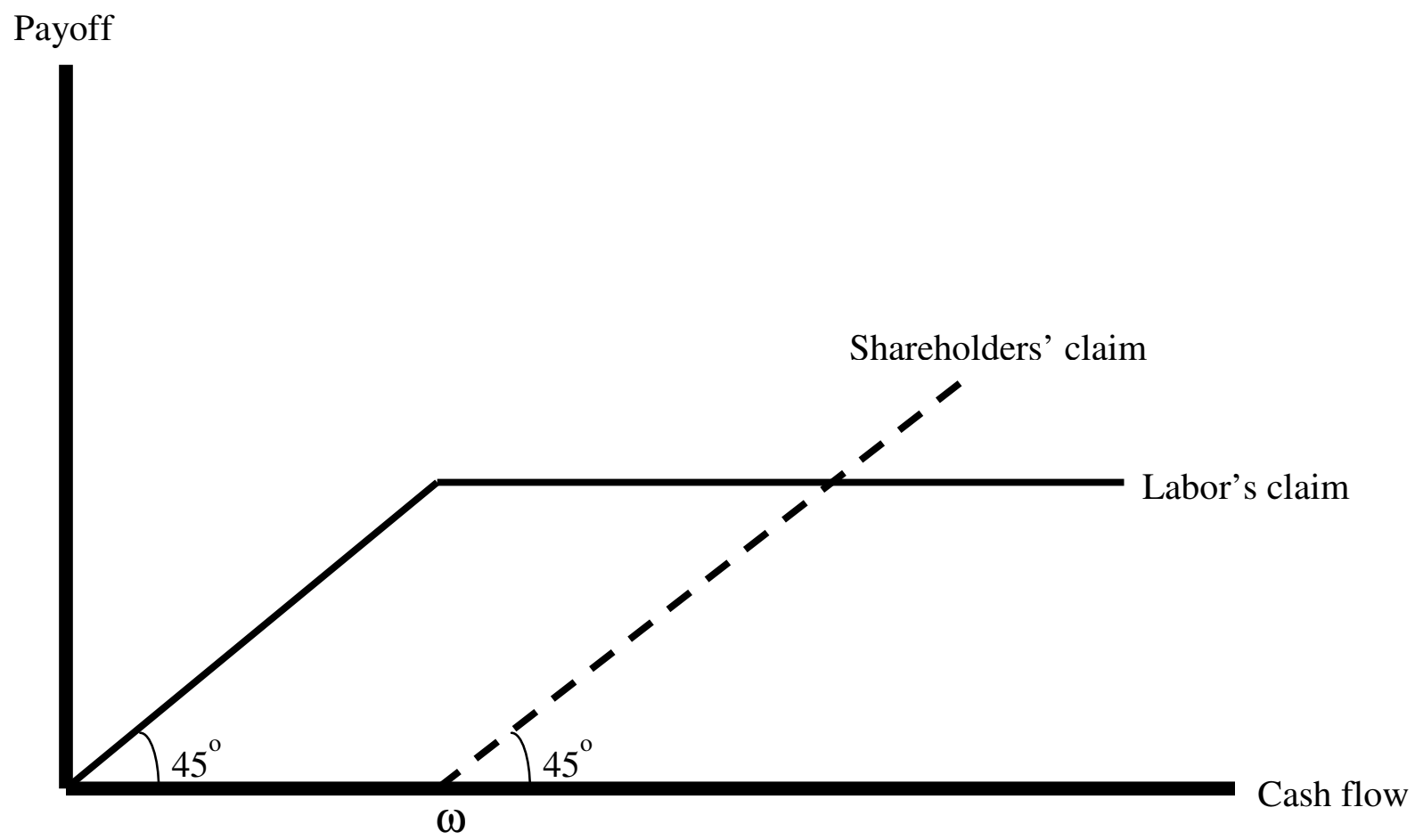




\section{Table 1: Distribution of labor ownership}

This table presents information on the distribution of employee equity ownership among our final sample of 226 labor voice firms. Initially, we identify 277 firms where employees own at least five percent of outstanding shares, as reported in the beneficial ownership section of the 1995 proxy statement. We drop 22 firms because the labor stake is voted by management. We drop an additional 29 firms because the labor stake was acquired after 1990. Thus, the final labor voice sample consists of 226 firms. In the table below, Ownership Range is the percent of outstanding shares controlled by employees as reported in the firm's 1995 proxy statement.

\begin{tabular}{lccc}
\hline Ownership Range & Frequency & $\begin{array}{c}\text { Relative } \\
\text { Frequency }\end{array}$ & $\begin{array}{c}\text { Cumulative } \\
\text { Frequency }\end{array}$ \\
\hline $5.00 \%-9.99 \%$ & 101 & $44.69 \%$ & $44.69 \%$ \\
$10.00 \%-14.99 \%$ & 65 & $28.76 \%$ & $73.45 \%$ \\
$15.00 \%-19.99 \%$ & 30 & $13.27 \%$ & $86.72 \%$ \\
$20.00 \%-24.99 \%$ & 15 & $6.64 \%$ & $93.36 \%$ \\
$25.00 \%$ and above & 15 & $6.64 \%$ & $100.00 \%$ \\
\hline Full sample & 226 & $100.00 \%$ & $100.00 \%$ \\
\hline Mean ownership & & & $13.16 \%$ \\
Median ownership & & & $10.60 \%$ \\
Minimum ownership & & & $5.00 \%$ \\
Maximum ownership & & & $68.20 \%$ \\
\hline
\end{tabular}




\section{Table 2: Univariate comparisons of labor control and other firms}

Employees at Labor Voice Firms control at least five percent of the firm's voting shares, while employees at Non-labor Voice Firms control less than five percent of the voting shares. Tobin's $q$ is calculated as the ratio of the sum of market value of common equity, book value of preferred equity, and book value of long-term debt to the book value of assets. For each year $t$, Net Capital Investment is average net investment in property, plant, and equipment over years $t, t-1$, and $t-2$ normalized by net property, plant, and equipment. $R \& D$ Investment is the ratio of $\mathrm{R} \& \mathrm{D}$ expenditure to total assets. Operating Risk is calculated as the standard deviation of annual return on assets over years $t, t-1, t-2$, and $t-3$. Sales Growth is calculated as the three-year average growth rate of real sales over years $t, t-1$, and $t-2$. Staff Growth is calculated in a similar manner. Total Factor Productivity is the residual of annual industry-specific Cobb-Douglas production functions estimated for each 2-digit SIC industry group. Sales per Employee is the natural logarithm of the ratio of annual sales to the number of employees. Insider Ownership is the proportion of outstanding voting shares owned by all officers and directors. Block Ownership is the percentage of voting shares controlled by unaffiliated holders of five percent or more. Board Size is the number of directors. Board Composition is the proportion of directors who are non-employee directors with no business or personal relationship with the firm or any of its employee-directors. Leadership Structure is a binary variable, which equals one when the CEO also serves as board chairman, zero otherwise. Managerial Equity Compensation is the ratio of the value of annual options granted the CEO to the CEO's total annual compensation. Investment Opportunities is the ratio of capital expenditures to total assets. Leverage is the ratio of long-term debt to total assets. Firm Size is the natural logarithm of total assets in 1994 constant dollars. Current Profitability is return on assets, calculated as the ratio of operating income to total assets at the beginning of the year. Historical Profitability is average return on assets over 1985-1989. Historical Tobin's $q$ is average Tobin's q ratio over 1985-1989. All non-corporate governance variables (except Historical Tobin's $q$ and Historical Profitability) are averages over 1995-2001. Corporate governance variables are from 1995 proxy statements and/or annual reports. For each variable,

$* * *, * *$, and * indicate that the value for Labor Voice Firms is significantly different from the value for Non-labor Voice Firms at the 1\%, 5\%, and 10\% levels, respectively. 
Table 2 continued: Univariate comparisons of labor control and other firms

\begin{tabular}{|c|c|c|c|c|c|c|}
\hline \multirow[t]{2}{*}{ Variable } & \multicolumn{3}{|c|}{ Labor voice firms } & \multicolumn{3}{|c|}{ Non-labor voice firms } \\
\hline & Sample & Mean & Median & Sample & Mean & Median \\
\hline \multicolumn{7}{|c|}{ Panel A: Dependent variables } \\
\hline Tobin's q & 209 & $1.019^{* * *}$ & $0.875^{* * *}$ & 1,704 & 1.433 & 1.026 \\
\hline Net capital investment & 209 & $0.084^{* * *}$ & $0.048^{* * *}$ & 1,658 & 0.133 & 0.078 \\
\hline$R \& D$ Investment & 226 & $0.013^{* * *}$ & 0.000 & 1,888 & 0.031 & 0.000 \\
\hline Operating risk & 210 & $0.035^{* * *}$ & $0.029^{* * *}$ & 1,705 & 0.055 & 0.039 \\
\hline Sales growth & 211 & $0.086^{* * *}$ & $0.057^{* * *}$ & 1,711 & 0.138 & 0.087 \\
\hline Staff growth & 202 & $0.049^{* * *}$ & $0.031^{* * *}$ & 1,632 & 0.098 & 0.054 \\
\hline Total factor productivity & 204 & $-0.011^{* * *}$ & $-0.032^{* * *}$ & 1,650 & 0.070 & 0.050 \\
\hline Sales per employee (log) & 208 & 5.279 & 5.137 & 1,694 & 5.241 & 5.158 \\
\hline \multicolumn{7}{|c|}{ Panel B: Control variables } \\
\hline Insider ownership & 226 & $13.595^{* * *}$ & $6.825^{* * *}$ & 1,888 & 22.008 & 14.650 \\
\hline Block ownership & 226 & $8.790^{* * *}$ & $6.000^{* *}$ & 1,888 & 10.703 & 7.515 \\
\hline Board size & 226 & $10.726^{* * *}$ & $10.000^{* * *}$ & 1,888 & 8.728 & 8.000 \\
\hline Board composition & 226 & $0.609^{* * *}$ & $0.640^{* * *}$ & 1,888 & 0.558 & 0.581 \\
\hline Leadership structure & 226 & $0.726^{*}$ & $1.000^{*}$ & 1,888 & 0.670 & 1.000 \\
\hline $\begin{array}{l}\text { Managerial equity } \\
\text { compensation }\end{array}$ & 226 & $0.182^{* *}$ & $0.121^{* * *}$ & 1,888 & 0.153 & 0.000 \\
\hline Investment opportunities & 211 & 0.055 & 0.048 & 1,714 & 0.059 & 0.049 \\
\hline Leverage & 211 & 0.195 & $0.195^{*}$ & 1,713 & 0.192 & 0.164 \\
\hline Firm size & 211 & $6.940^{* * *}$ & $6.890^{* * *}$ & 1,714 & 5.892 & 5.886 \\
\hline Current profitability & 211 & $0.139^{* *}$ & 0.145 & 1,709 & 0.125 & 0.133 \\
\hline Historical profitability & 207 & 0.157 & 0.154 & 1,610 & 0.148 & 0.143 \\
\hline Historical Tobin's q & 208 & $0.908^{* * *}$ & $0.850^{* * *}$ & 1,647 & 1.491 & 1.025 \\
\hline
\end{tabular}




\section{Table 3: Market valuation and labor control}

The dependent variable in these regressions is Tobin's q, calculated as the ratio of the sum of market value of common equity, book value of preferred equity, and book value of long-term debt to the book value of assets. Labor Ownership is the proportion of outstanding voting shares controlled by employees; 5\% Labor Dummy is an indicator variable, which equals one if labor ownership is at least 5\%, zero otherwise; Managerial Equity Compensation is the ratio of the value of annual options granted the CEO to the CEO's total annual compensation; Insider Ownership I measures managerial equity ownership up to 5\%; Insider Ownership II measures managerial equity ownership between 5\% and 25\%; Insider Ownership III measures managerial equity ownership greater than $25 \%$; Block Ownership is the proportion of outstanding voting shares controlled by unaffiliated holders of five percent or more; Board Size is the number of directors; Board Composition is the proportion of directors who are non-employee directors with no business or personal relationship with the firm or any of its employee-directors; Leadership Structure is a binary variable, which equals one when the CEO also serves as board chairman, zero otherwise; Investment Opportunities is the ratio of capital expenditures to total assets; Leverage is the ratio of long-term debt to total assets; Firm Size is the natural logarithm of total assets in 1994 constant dollars; Current Profitability is the ratio of operating income to total assets at the beginning of the year; Historical Profitability is the average of return on assets over 1985-1989; Historical Market Valuation is the average of Tobin's q ratio over 1985-1989. All non-corporate governance variables (except Historical Market Valuation and Historical Profitability) are averages over 1995-2001. Corporate governance variables are from 1995 proxy statements and/or annual reports. Each regression includes 2-digit SIC industry dummies to control for unobservable industry factors. Statistically significant variables are shown in bold typeface. The number in parentheses under sample size is the number of firms satisfying the definition of labor firms in each regression. 
Table 3 continued: Market valuation and labor control

\begin{tabular}{|c|c|c|c|c|}
\hline & I & II & III & IV \\
\hline Labor ownership & $\begin{array}{c}\mathbf{- 0 . 0 1 5 8} \\
(0.01)\end{array}$ & --- & $\begin{array}{c}\mathbf{- 0 . 0 2 0 9} \\
(0.01)\end{array}$ & --- \\
\hline $5 \%$ labor dummy & --- & $\begin{array}{c}\mathbf{- 0 . 2 2 9 6} \\
(0.01)\end{array}$ & --- & $\begin{array}{c}\mathbf{- 0 . 2 7 9 8} \\
(0.01)\end{array}$ \\
\hline $\begin{array}{l}\text { Managerial equity } \\
\text { compensation }\end{array}$ & $\begin{array}{c}\mathbf{1 . 2 5 7 3} \\
(0.01)\end{array}$ & $\begin{array}{c}\mathbf{1 . 2 6 7 6} \\
(0.01)\end{array}$ & $\begin{array}{c}\mathbf{1 . 4 7 0 2} \\
(0.01)\end{array}$ & $\begin{array}{c}\mathbf{1 . 4 8 3 6} \\
(0.01)\end{array}$ \\
\hline Insider ownership I & $\begin{array}{c}0.0292 \\
(0.23)\end{array}$ & $\begin{array}{c}0.0289 \\
(0.24)\end{array}$ & $\begin{array}{c}0.0343 \\
(0.19)\end{array}$ & $\begin{array}{c}0.0336 \\
(0.20)\end{array}$ \\
\hline Insider ownership II & $\begin{array}{c}-\mathbf{- 0 . 0 1 0 8} \\
(0.02)\end{array}$ & $\begin{array}{c}-\mathbf{- 0 . 0 1 0 5} \\
(0.03)\end{array}$ & $\begin{array}{c}-\mathbf{- 0 . 0 0 8 8} \\
(0.08)\end{array}$ & $\begin{array}{c}\mathbf{- 0 . 0 0 8 5} \\
(0.10)\end{array}$ \\
\hline Insider ownership III & $\begin{array}{c}-0.0004 \\
(0.86)\end{array}$ & $\begin{array}{c}-0.0004 \\
(0.87)\end{array}$ & $\begin{array}{c}-0.0029 \\
(0.25)\end{array}$ & $\begin{array}{c}-0.0028 \\
(0.27)\end{array}$ \\
\hline Block ownership & $\begin{array}{c}\mathbf{- 0 . 0 0 7 7} \\
(0.01)\end{array}$ & $\begin{array}{c}\mathbf{- 0 . 0 0 7 5} \\
(0.01)\end{array}$ & $\begin{array}{c}\mathbf{- 0 . 0 1 1 2} \\
(0.01)\end{array}$ & $\begin{array}{c}\mathbf{- 0 . 0 1 1 0} \\
(0.01)\end{array}$ \\
\hline Board size & $\begin{array}{c}\mathbf{- 0 . 0 2 1 3} \\
(0.05)\end{array}$ & $\begin{array}{c}\mathbf{- 0 . 0 2 0 1} \\
(0.06)\end{array}$ & $\begin{array}{c}\mathbf{- 0 . 0 2 7 0} \\
(0.03)\end{array}$ & $\begin{array}{c}\mathbf{- 0 . 0 2 5 8} \\
(0.03)\end{array}$ \\
\hline Board composition & $\begin{array}{c}0.1006 \\
(0.47)\end{array}$ & $\begin{array}{c}0.1090 \\
(0.44)\end{array}$ & $\begin{array}{c}0.0332 \\
(0.83)\end{array}$ & $\begin{array}{c}0.0373 \\
(0.81)\end{array}$ \\
\hline Leadership structure & $\begin{array}{c}-0.0316 \\
(0.57)\end{array}$ & $\begin{array}{c}-0.0272 \\
(0.62)\end{array}$ & $\begin{array}{c}-0.0511 \\
(0.39)\end{array}$ & $\begin{array}{c}-0.0448 \\
(0.45)\end{array}$ \\
\hline $\begin{array}{l}\text { Investment } \\
\text { opportunities }\end{array}$ & $\begin{array}{c}\mathbf{1 . 6 1 4 9} \\
(0.02)\end{array}$ & $\begin{array}{c}\mathbf{1 . 6 4 9 8} \\
(0.01)\end{array}$ & $\begin{array}{c}\mathbf{2 . 0 9 8 4} \\
(0.01)\end{array}$ & $\begin{array}{c}\mathbf{2 . 1 4 9 4} \\
(0.01)\end{array}$ \\
\hline Leverage & $\begin{array}{c}0.0440 \\
(0.76)\end{array}$ & $\begin{array}{c}0.0492 \\
(0.73)\end{array}$ & $\begin{array}{c}-0.0726 \\
(0.65)\end{array}$ & $\begin{array}{c}-0.0676 \\
(0.67)\end{array}$ \\
\hline Firm size & $\begin{array}{c}-0.0317 \\
(0.14)\end{array}$ & $\begin{array}{c}-0.0322 \\
(0.14)\end{array}$ & $\begin{array}{c}-0.0336 \\
(0.16)\end{array}$ & $\begin{array}{c}-0.0344 \\
(0.15)\end{array}$ \\
\hline Current profitability & $\begin{array}{c}\mathbf{0 . 8 5 9 4} \\
(0.01)\end{array}$ & $\begin{array}{c}\mathbf{0 . 8 5 9 9} \\
(0.01)\end{array}$ & $\begin{array}{c}\mathbf{0 . 6 5 2 7} \\
(0.01)\end{array}$ & $\begin{array}{c}\mathbf{0 . 6 5 2 7} \\
(0.01)\end{array}$ \\
\hline $\begin{array}{l}\text { Historical } \\
\text { profitability }\end{array}$ & --- & --- & $\begin{array}{c}\mathbf{- 1 . 3 4 5 6} \\
(0.01)\end{array}$ & $\begin{array}{c}\mathbf{- 1 . 3 4 6 5} \\
(0.01)\end{array}$ \\
\hline $\begin{array}{l}\text { Historical market } \\
\text { valuation }\end{array}$ & $\begin{array}{c}\mathbf{0 . 2 1 0 1} \\
(0.01)\end{array}$ & $\begin{array}{c}\mathbf{0 . 2 1 0 4} \\
(0.01)\end{array}$ & --- & --- \\
\hline $\begin{array}{l}\text { Sample size } \\
\text { (Labor voice firms) }\end{array}$ & $\begin{array}{l}1,704 \\
(196)\end{array}$ & $\begin{array}{l}1,704 \\
(196)\end{array}$ & $\begin{array}{l}1,667 \\
(193)\end{array}$ & $\begin{array}{l}1,667 \\
(193)\end{array}$ \\
\hline$R$-square & 0.3862 & 0.3857 & 0.2784 & 0.2770 \\
\hline Model F & $\begin{array}{l}13.29 \\
(0.01)\end{array}$ & $\begin{array}{l}13.26 \\
(0.01)\end{array}$ & $\begin{array}{c}7.86 \\
(0.01)\end{array}$ & $\begin{array}{c}7.80 \\
(0.01)\end{array}$ \\
\hline
\end{tabular}


Table 4: Market valuation and labor control robustness check (higher levels of labor ownership)

The dependent variable in these regressions is Tobin's q, calculated as the ratio of the sum of market value of common equity, book value of preferred equity, and book value of long-term debt to the book value of assets. 10\% Labor Dummy, 15\% Labor Dummy, and 20\% Labor Dummy are indicator variables which equal one if labor ownership is at least $10 \%, 15 \%$, and 20\%, respectively, zero otherwise; Managerial Equity Compensation is the ratio of the value of annual options granted the CEO to the CEO's total annual compensation; Insider Ownership I measures managerial equity ownership up to 5\%; Insider Ownership II measures managerial equity ownership between 5\% and 25\%; Insider Ownership III measures managerial equity ownership greater than 25\%; Block Ownership is the proportion of outstanding voting shares controlled by unaffiliated holders of five percent or more; Board Size is the number of directors; Board Composition is the proportion of directors who are non-employee directors with no business or personal relationship with the firm or any of its employee-directors; Leadership Structure is a binary variable, which equals one when the CEO also serves as board chairman, zero otherwise; Investment Opportunities is the ratio of capital expenditures to total assets; Leverage is the ratio of long-term debt to total assets; Firm Size is the natural logarithm of total assets in 1994 constant dollars; Current Profitability is the ratio of operating income to total assets at the beginning of the year; Historical Profitability is the average of return on assets over 1985-1989. All non-corporate governance variables (except Historical Profitability) are averages over 1995-2001. Corporate governance variables are from 1995 proxy statements and/or annual reports. Each regression includes 2-digit SIC industry dummies to control for unobservable industry factors. Statistically significant variables are shown in bold typeface. The number in parentheses under sample size is the number of firms satisfying the definition of labor firms in each regression. 
Table 4 continued: Market valuation and labor control robustness check (higher levels of labor ownership)

\begin{tabular}{|c|c|c|c|}
\hline & I & II & III \\
\hline $10 \%$ labor dummy & $\begin{array}{c}\mathbf{- 0 . 3 8 8 4} \\
(0.01)\end{array}$ & --- & --- \\
\hline $15 \%$ labor dummy & --- & $\begin{array}{c}\mathbf{- 0 . 4 9 0 9} \\
(0.01)\end{array}$ & --- \\
\hline $20 \%$ labor dummy & --- & --- & $\begin{array}{c}\mathbf{- 0 . 5 3 0 1} \\
(0.03)\end{array}$ \\
\hline $\begin{array}{l}\text { Managerial equity } \\
\text { compensation }\end{array}$ & $\begin{array}{c}\mathbf{1 . 4 7 8 1} \\
(0.01)\end{array}$ & $\begin{array}{c}\mathbf{1 . 5 1 2 7} \\
(0.01)\end{array}$ & $\begin{array}{r}\mathbf{1 . 5 4 9 7} \\
(0.01)\end{array}$ \\
\hline Insider ownership I & $\begin{array}{c}0.0415 \\
(0.13)\end{array}$ & $\begin{array}{c}0.0397 \\
(0.17)\end{array}$ & $\begin{array}{c}0.0383 \\
(0.19)\end{array}$ \\
\hline Insider ownership II & $\begin{array}{c}\mathbf{- 0 . 0 0 9 0} \\
(0.09)\end{array}$ & $\begin{array}{c}\mathbf{- 0 . 0 0 9 1} \\
(0.10)\end{array}$ & $\begin{array}{c}\mathbf{- 0 . 0 0 9 5} \\
(0.09)\end{array}$ \\
\hline Insider ownership III & $\begin{array}{c}-0.0029 \\
(0.28)\end{array}$ & $\begin{array}{c}-0.0028 \\
(0.30)\end{array}$ & $\begin{array}{c}-0.0024 \\
(0.39)\end{array}$ \\
\hline Block ownership & $\begin{array}{c}-\mathbf{- 0 . 0 1 0 8} \\
(0.01)\end{array}$ & $\begin{array}{c}-\mathbf{- 0 . 0 1 1 1} \\
(0.01)\end{array}$ & $\begin{array}{c}\mathbf{- 0 . 0 1 1 4} \\
(0.01)\end{array}$ \\
\hline Board size & $\begin{array}{c}\mathbf{- 0 . 0 3 0 8} \\
(0.02)\end{array}$ & $\begin{array}{c}\mathbf{- 0 . 0 3 4 5} \\
(0.01)\end{array}$ & $\begin{array}{c}\mathbf{- 0 . 0 3 5 2} \\
(0.01)\end{array}$ \\
\hline Board composition & $\begin{array}{c}0.0685 \\
(0.66)\end{array}$ & $\begin{array}{c}0.0879 \\
(0.59)\end{array}$ & $\begin{array}{c}0.0864 \\
(0.60)\end{array}$ \\
\hline Leadership structure & $\begin{array}{c}-0.0593 \\
(0.34)\end{array}$ & $\begin{array}{c}-0.0656 \\
(0.30)\end{array}$ & $\begin{array}{c}-0.0721 \\
(0.27)\end{array}$ \\
\hline $\begin{array}{l}\text { Investment } \\
\text { opportunities }\end{array}$ & $\begin{array}{c}2.0923 \\
(0.01)\end{array}$ & $\begin{array}{c}2.0992 \\
(0.01)\end{array}$ & $\begin{array}{r}\mathbf{2 . 1 0 7 7} \\
(0.01)\end{array}$ \\
\hline Leverage & $\begin{array}{c}-0.0752 \\
(0.64)\end{array}$ & $\begin{array}{c}-0.0599 \\
(0.72)\end{array}$ & $\begin{array}{c}-0.0566 \\
(0.74)\end{array}$ \\
\hline Firm size & $\begin{array}{c}-0.0281 \\
(0.25)\end{array}$ & $\begin{array}{c}-0.0269 \\
(0.29)\end{array}$ & $\begin{array}{c}-0.0266 \\
(0.31)\end{array}$ \\
\hline Current profitability & $\begin{array}{c}\mathbf{0 . 5 8 7 5} \\
(0.03)\end{array}$ & $\begin{array}{c}\mathbf{0 . 5 6 2 0} \\
(0.05)\end{array}$ & $\begin{array}{c}\mathbf{0 . 5 4 3 1} \\
(0.06)\end{array}$ \\
\hline $\begin{array}{l}\text { Historical } \\
\text { profitability }\end{array}$ & $\begin{array}{c}\mathbf{- 1 . 3 8 0 3} \\
(0.01)\end{array}$ & $\begin{array}{c}\mathbf{- 1 . 3 9 0 8} \\
(0.01)\end{array}$ & $\begin{array}{c}\mathbf{- 1 . 4 0 0 0} \\
(0.01)\end{array}$ \\
\hline $\begin{array}{l}\text { Sample size } \\
\text { (Labor voice firms) }\end{array}$ & $\begin{array}{l}1,579 \\
(106)\end{array}$ & $\begin{array}{l}1,525 \\
(52)\end{array}$ & $\begin{array}{c}1,496 \\
(23)\end{array}$ \\
\hline$R$-square & 0.2712 & 0.2716 & 0.2720 \\
\hline Model F & $\begin{array}{c}7.16 \\
(0.01)\end{array}$ & $\begin{array}{c}6.91 \\
(0.01)\end{array}$ & $\begin{array}{c}6.79 \\
(0.01)\end{array}$ \\
\hline
\end{tabular}




\section{Table 5: Market valuation and labor control robustness check}

(labor owns the largest single block)

The dependent variable in these regressions is Tobin's q, calculated as the ratio of the sum of market value of common equity, book value of preferred equity, and book value of long-term debt to the book value of assets. 10\% Labor Dummy, 15\% Labor Dummy, and 20\% Labor Dummy are indicator variables which equal one if labor ownership is at least $10 \%$, $15 \%$, and $20 \%$, respectively, zero otherwise. In each labor firm, employees own the largest single equity block. Managerial Equity Compensation is the ratio of the value of annual options granted the CEO to the CEO's total annual compensation; Insider Ownership I measures managerial equity ownership up to 5\%; Insider Ownership II measures managerial equity ownership between 5\% and 25\%; Insider Ownership III measures managerial equity ownership greater than 25\%; Block Ownership is the proportion of outstanding voting shares controlled by unaffiliated holders of five percent or more; Board Size is the number of directors; Board Composition is the proportion of directors who are non-employee directors with no business or personal relationship with the firm or any of its employee-directors; Leadership Structure is a binary variable, which equals one when the CEO also serves as board chairman, zero otherwise; Investment Opportunities is the ratio of capital expenditures to total assets; Leverage is the ratio of long-term debt to total assets; Firm Size is the natural logarithm of total assets in 1994 constant dollars; Current Profitability is the ratio of operating income to total assets at the beginning of the year; Historical Profitability is the average of return on assets over 1985-1989. All non-corporate governance variables (except Historical Profitability) are averages over 1995-2001. Corporate governance variables are from 1995 proxy statements and/or annual reports. Each regression includes 2-digit SIC industry dummies to control for unobservable industry factors. Statistically significant variables are shown in bold typeface. The number in parentheses under sample size is the number of firms satisfying the definition of labor firms in each regression. 
Table 5 continued: Market valuation and labor control robustness check (labor owns the largest single block)

\begin{tabular}{|c|c|c|c|}
\hline & I & II & III \\
\hline $10 \%$ labor dummy & $\begin{array}{c}\mathbf{- 0 . 4 1 5 0} \\
(0.01)\end{array}$ & --- & --- \\
\hline $15 \%$ labor dummy & --- & $\begin{array}{c}\mathbf{- 0 . 5 3 8 1} \\
(0.01)\end{array}$ & --- \\
\hline $20 \%$ labor dummy & --- & --- & $\begin{array}{c}\mathbf{- 0 . 5 3 0 1} \\
(0.06)\end{array}$ \\
\hline $\begin{array}{l}\text { Managerial equity } \\
\text { compensation }\end{array}$ & $\begin{array}{c}\mathbf{1 . 5 0 6 7} \\
(0.01)\end{array}$ & $\begin{array}{l}\mathbf{1 . 5 2 0 3} \\
(0.01)\end{array}$ & $\begin{array}{c}\mathbf{1 . 5 4 4 6} \\
(0.01)\end{array}$ \\
\hline Insider ownership I & $\begin{array}{c}0.0388 \\
(0.18)\end{array}$ & $\begin{array}{c}0.0405 \\
(0.16)\end{array}$ & $\begin{array}{c}0.0390 \\
(0.19)\end{array}$ \\
\hline Insider ownership II & $\begin{array}{c}\mathbf{- 0 . 0 0 9 4} \\
(0.09)\end{array}$ & $\begin{array}{c}\mathbf{- 0 . 0 0 9 6} \\
(0.09)\end{array}$ & $\begin{array}{c}\mathbf{- 0 . 0 0 9 4} \\
(0.10)\end{array}$ \\
\hline Insider ownership III & $\begin{array}{c}-0.0025 \\
(0.36)\end{array}$ & $\begin{array}{c}-0.0025 \\
(0.37)\end{array}$ & $\begin{array}{c}-0.0024 \\
(0.38)\end{array}$ \\
\hline Block ownership & $\begin{array}{c}\mathbf{- 0 . 0 1 1 2} \\
(0.01)\end{array}$ & $\begin{array}{c}\mathbf{- 0 . 0 1 1 3} \\
(0.01)\end{array}$ & $\begin{array}{c}\mathbf{- 0 . 0 1 1 4} \\
(0.01)\end{array}$ \\
\hline Board size & $\begin{array}{c}\mathbf{- 0 . 0 3 1 7} \\
(0.02)\end{array}$ & $\begin{array}{c}\mathbf{- 0 . 0 3 4 7} \\
(0.01)\end{array}$ & $\begin{array}{c}\mathbf{- 0 . 0 3 5 5} \\
(0.01)\end{array}$ \\
\hline Board composition & $\begin{array}{c}0.0784 \\
(0.63)\end{array}$ & $\begin{array}{c}0.0839 \\
(0.61)\end{array}$ & $\begin{array}{r}0.0857 \\
(0.61)\end{array}$ \\
\hline Leadership structure & $\begin{array}{c}-0.0641 \\
(0.32)\end{array}$ & $\begin{array}{c}-0.0722 \\
(0.26)\end{array}$ & $\begin{array}{c}-0.0727 \\
(0.27)\end{array}$ \\
\hline $\begin{array}{l}\text { Investment } \\
\text { opportunities }\end{array}$ & $\begin{array}{c}2.2271 \\
(0.01)\end{array}$ & $\begin{array}{c}\mathbf{2 . 1 6 0 9} \\
(0.01)\end{array}$ & $\begin{array}{c}2.1139 \\
(0.01)\end{array}$ \\
\hline Leverage & $\begin{array}{c}-0.0551 \\
(0.74)\end{array}$ & $\begin{array}{c}-0.0569 \\
(0.73)\end{array}$ & $\begin{array}{c}-0.0536 \\
(0.75)\end{array}$ \\
\hline Firm size & $\begin{array}{c}-0.0290 \\
(0.25)\end{array}$ & $\begin{array}{c}-0.0258 \\
(0.32)\end{array}$ & $\begin{array}{c}-0.0256 \\
(0.33)\end{array}$ \\
\hline Current profitability & $\begin{array}{c}\mathbf{0 . 5 7 0 6} \\
(0.04)\end{array}$ & $\begin{array}{c}\mathbf{0 . 5 5 1 7} \\
(0.05)\end{array}$ & $\begin{array}{c}\mathbf{0 . 5 4 1 0} \\
(0.06)\end{array}$ \\
\hline $\begin{array}{l}\text { Historical } \\
\text { profitability }\end{array}$ & $\begin{array}{c}\mathbf{- 1 . 3 9 5 0} \\
(0.01)\end{array}$ & $\begin{array}{c}\mathbf{- 1 . 4 0 0 6} \\
(0.01)\end{array}$ & $\begin{array}{c}\mathbf{- 1 . 4 0 2 9} \\
(0.01)\end{array}$ \\
\hline $\begin{array}{l}\text { Sample size } \\
\text { (Labor voice firms) }\end{array}$ & $\begin{array}{c}1,531 \\
(58)\end{array}$ & $\begin{array}{c}1,508 \\
(35)\end{array}$ & $\begin{array}{c}1,490 \\
(17)\end{array}$ \\
\hline$R$-square & 0.2715 & 0.2717 & 0.2719 \\
\hline Model F & $\begin{array}{c}6.94 \\
(0.01)\end{array}$ & $\begin{array}{c}6.84 \\
(0.01)\end{array}$ & $\begin{array}{c}6.76 \\
(0.01)\end{array}$ \\
\hline
\end{tabular}




\section{Table 6: Corporate operations and labor control}

This table summarizes results from 32 regressions relating several aspects of corporate operations to measures of labor control. $D K / K$ is net investment in property, plant, and equipment normalized by net property, plant, and equipment. $R \& D$ is the ratio of research and development expenditure to total assets. For each year $t, V R O A$ is calculated as the standard deviation of annual return on assets over years $t, t-1, t-2$, and $t-3$. DSLE is three-year average growth rate of real sales. DSTF is three-year average growth rate of employees. TFP is the residual of annual industry-specific Cobb-Douglas production functions estimated for each 2digit SIC industry group. SPE is the natural logarithm of the ratio of annual sales to the number of employees. Labor Ownership is the proportion of outstanding shares voted by employees. The variables 5\% Labor Dummy, 10\% Labor Dummy, and 15\% Labor Dummy are indicator variables which equal one if labor ownership is at least $5 \%, 10 \%$, and $15 \% \%$, respectively, zero otherwise. Each regression includes controls for managerial equity compensation as measured by the ratio of the value of annual options granted the CEO to the CEO's total annual compensation, insider ownership, block ownership, board size, board composition, leadership structure, investment opportunities as measured by the ratio of capital expenditures to total assets, leverage as measured by the ratio of long-term debt to total assets, firm size as measured by the natural logarithm of total assets in 1994 constant dollars, and historical profitability as measured by average annual return on assets over 1985-1989, as well as 2-digit SIC industry dummies to control for unobservable industry factors. All non-corporate governance variables (except historical profitability) are averages over 1995-2001. Corporate governance variables are from 1995 proxy statements and/or annual reports. The first entry in each cell is the coefficient of the labor voice variable from each regression. P-values are shown in parentheses under each regression coefficient. The first number in the square brackets in each cell is the sample size; it is followed by the number of firms satisfying the definition of labor-influenced firms in each regression. Regressions in the column labeled R\&D I are Tobit regressions estimated over all sample firms, while those in the column labeled R\&D II are regressions estimated over firms with non-zero R\&D expenditures. 
Table 6 continued: Corporate operations and labor control

\begin{tabular}{|c|c|c|c|c|c|c|c|c|}
\hline & $I$ & II & III & $I V$ & $V$ & $\boldsymbol{V I}$ & VII & VIII \\
\hline & $D K / K$ & $R \& D I$ & $R \& D I I$ & VROA & DSLE & DSTF & $T F P$ & $S P E$ \\
\hline Labor ownership & $\begin{array}{c}-0.0020 \\
(0.04) \\
{[1637 / 194]}\end{array}$ & $\begin{array}{c}-0.0004 \\
(0.61) \\
{[1676 / 195]}\end{array}$ & $\begin{array}{c}-0.0118 \\
(0.05) \\
{[738 / 89]}\end{array}$ & $\begin{array}{c}-0.0005 \\
(0.01) \\
{[1726 / 199]}\end{array}$ & $\begin{array}{c}-0.0022 \\
(0.02) \\
{[1671 / 195]}\end{array}$ & $\begin{array}{c}-0.0019 \\
(0.02) \\
{[1676 / 195]}\end{array}$ & $\begin{array}{c}-0.0043 \\
(0.05) \\
{[1850 / 204]}\end{array}$ & $\begin{array}{c}-0.0054 \\
(0.06) \\
{[1886 / 206]}\end{array}$ \\
\hline $5 \%$ labor dummy & $\begin{array}{c}-0.0259 \\
(0.07) \\
{[1637 / 194]}\end{array}$ & $\begin{array}{c}-0.0097 \\
(0.35) \\
{[1676 / 195]}\end{array}$ & $\begin{array}{c}-0.2007 \\
(0.03) \\
{[738 / 89]}\end{array}$ & $\begin{array}{c}-0.0081 \\
(0.01) \\
{[1726 / 199]}\end{array}$ & $\begin{array}{c}-0.0335 \\
(0.02) \\
{[1671 / 195]}\end{array}$ & $\begin{array}{c}-0.0316 \\
(0.02) \\
{[1676 / 195]}\end{array}$ & $\begin{array}{c}-0.0681 \\
(0.05) \\
{[1850 / 204]}\end{array}$ & $\begin{array}{c}-0.0731 \\
(0.10) \\
{[1886 / 206]}\end{array}$ \\
\hline $10 \%$ labor dummy & $\begin{array}{c}-0.0272 \\
(0.15) \\
{[1550 / 107]}\end{array}$ & $\begin{array}{c}-0.0140 \\
(0.31) \\
{[1589 / 108]}\end{array}$ & $\begin{array}{c}-0.2400 \\
(0.05) \\
{[697 / 48]}\end{array}$ & $\begin{array}{c}-0.0076 \\
(0.08) \\
{[1637 / 110]}\end{array}$ & $\begin{array}{c}-0.0367 \\
(0.05) \\
{[1584 / 108]}\end{array}$ & $\begin{array}{c}-0.0350 \\
(0.04) \\
{[1589 / 108]}\end{array}$ & $\begin{array}{c}-0.0803 \\
(0.09) \\
{[1759 / 113]}\end{array}$ & $\begin{array}{c}-0.0943 \\
(0.12) \\
{[1795 / 115]}\end{array}$ \\
\hline $15 \%$ labor dummy & $\begin{array}{c}-0.0461 \\
(0.08) \\
{[1497 / 54]}\end{array}$ & $\begin{array}{c}0.0026 \\
(0.89) \\
{[1535 / 54]}\end{array}$ & $\begin{array}{c}-0.0531 \\
(0.74) \\
{[674 / 25]}\end{array}$ & $\begin{array}{c}-0.0113 \\
(0.06) \\
{[1582 / 55]}\end{array}$ & $\begin{array}{c}-0.0522 \\
(0.05) \\
{[1530 / 54]}\end{array}$ & $\begin{array}{c}-0.0448 \\
(0.07) \\
{[1535 / 54]}\end{array}$ & $\begin{array}{c}-0.1497 \\
(0.02) \\
{[1700 / 54]}\end{array}$ & $\begin{array}{c}-0.1784 \\
(0.04) \\
{[1735 / 55]}\end{array}$ \\
\hline
\end{tabular}

